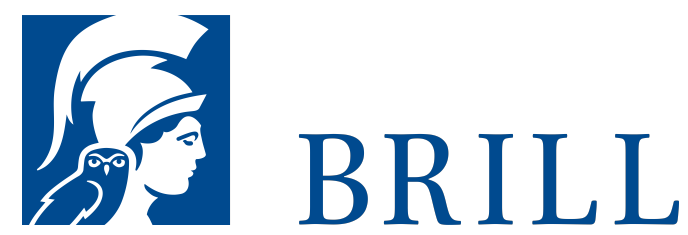

\title{
Nach der Gesellschaft
}

Infogene Welten - anthropologische Zukünfte

Author: Manfred Faßler

Die globalen Verbreitungen digitaler Netzwerke schwächen und zerstören zusehends einen alten Mythos: die Gesellschaft. Die Menschheit ist dabei, ihre Organisationsweisen und Lebenszustände grundlegend zu verändern. Die These dieses Buches ist: Gesellschaften verlieren ihre Vererbungstauglichkeiten und damit ihre Reproduktionstauglichkeit. Sie verlieren sie an komplexe ökonomische, projektgebundene, künstlerische, kollaborative Informationsrealitäten, die für ihre selektiven Vernetzungen, ihre koordinierenden Verabredungen und ihre Innovationsfähigkeit des Legalitäts- und Legitimiationsraumes der Gesellschaft nicht mehr bedürfen. Gegenwärtig steht dafür das Kürzel: Web 2.o.

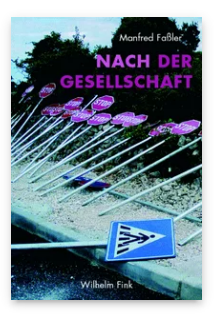

Pages: 307

Seiten

Language:

German

Subjects:

Sociology \&

Anthropology,

Social Sciences

Publisher: Brill |

Fink

E-Book (PDF)

Released online:

og Dec 2019

ISBN: $978-3-$

8467-4875-6

List price

Paperback

Publication date:

19 Aug 2009

ISBN: 978-3-

7705-4875-O

List price 
For more information see brill.com

Order information: Order online at brill.com +44330 333 0049 | customerservices@brill.com Submission information: brill.com/authors

Titles published by Brill | Fink, Brill | mentis or Brill | Schöningh: +49(o)715413279216| brill@brocom.de 